\title{
Comparison of serum amylase level between dipeptidyl peptidase-4 inhibitor and GLP-1 analog administration in patients with type 2 diabetes mellitus
}

\author{
Junichi Okada ${ }^{1,2^{*}}$, Eijiro Yamada ${ }^{1}$, Yawara Niijima ${ }^{2}$, Shuichi Okada ${ }^{1,2^{*}}$ (D) and Masanobu Yamada
}

\begin{abstract}
We monitored serum amylase level in patients with type 2 diabetes mellitus (T2DM) prescribed either dipeptidyl peptidase-4 inhibitor or GLP-1 analog (GLP-1 group) as monotherapy. Patients were treated for a 36-month period. All subjects were non-smoker and did not take any alcoholic beverages. Forty-nine patients were prescribed DPP4is (DPP4i group), and 9 patients were prescribed GLP-1 analogs (GLP-1 group). The median of serum amylase levels in DPP4is group was $73 \mathrm{U} / \mathrm{mL}$ and the median of serum amylase levels in GLP-1 analog group was 76 . Thus, there was no statistical significance between the two groups. However, the increased serum amylase levels in the three patients were observed only in the DPP4is group. One strength of the current study is that the serum amylase level was consistently measured in all subjects, and those subjects had been treated with either DPP4is or GLP-1 analogs as monotherapy. The incidence of elevated serum pancreatic amylase levels beyond normal range was calculated as $6.12 \%$ in the DPP4is group although the frequency was $0 \%$ in the GLP-1 analog group. Measurement of serum amylase consistently might have clinical meaning to catch the onset of pancreatitis and minimize the side effects due to DPP4is and GLP-1 analogs.
\end{abstract}

\section{To the Editor:}

Rathish et al. reported a significantly higher lipase level among the dipeptidyl peptidase-4 inhibitor (DPP4i) users in comparison with other oral hypoglycemic drug users [1]. On the other hand, whether DPP4is or GLP-1 analog users are associated with pancreatitis is not concluded yet $[2,3]$. On the other hand, elevated serum amylase level is necessary for diagnosis of pancreatitis. Therefore, we consistently measured serum amylase levels in patients with type 2 diabetes mellitus (T2DM) before and after being prescribed either DPP4is or GLP-1 analogs as monotherapy.

Patients consistently visited our hospital for follow-up examination once a month, and blood glucose and HbA1c were measured from the same casual blood samples. In parallel, serum amylase level was measured every

\footnotetext{
* Correspondence: okadash@gunma-u.ac.jp

${ }^{1}$ Department of Medicine and Molecular Science, Gunma University Graduate School of Medicine, 3-39-15 Showa-machi, Maebashi, Gunma 371-8511, Japan

Full list of author information is available at the end of the article
}

other month. Body weight and blood pressure were also measured each time. The present study includes patients that were followed up in this manner for a 36-month period. All subjects were non-smoker and did not take any alcoholic beverages. Blood samples for the relevant investigations were analyzed at our hospital. Procedures for measurement of the above investigations were well established and routinely done at the above laboratory [4].

Forty-nine patients were prescribed DPP4is (DPP4is group). The median age was 69 years (range 42 88 years). Sitagliptin was prescribed to 31 patients, vildagliptin was prescribed to 12 patients, linagliptin was prescribed to 4 patients, and anagliptin was prescribed to 2 patients. Nine patients were prescribed GLP-1 analogs (GLP-1 analogs group). The median age was 67 years (range 38 79 years). Dulaglutide was prescribed to 8 patients, and lixisenatide was prescribed to 1 patient. All of the patients did not suffer any type of pancreatic disease prior to start of either DPP4is of GLP-1 analogs.

(C) The Author(s). 2019 Open Access This article is distributed under the terms of the Creative Commons Attribution 4.0 International License (http://creativecommons.org/licenses/by/4.0/), which permits unrestricted use, distribution, and reproduction in any medium, provided you give appropriate credit to the original author(s) and the source, provide a link to the Creative Commons license, and indicate if changes were made. The Creative Commons Public Domain Dedication waiver (http://creativecommons.org/publicdomain/zero/1.0/) applies to the data made available in this article, unless otherwise stated. 
We did not find statistically, significant difference about body weight, duration of diabetes mellitus, blood glucose, and HbA1c levels during the observation period between the DPP4is group and GLP-1 analog group. The median of serum amylase levels in the DPP4is group was $73 \mathrm{U} / \mathrm{mL}$ (range 33 209, reference range 49 136). The median of serum amylase levels in GLP-1 analogs group was 76 (range 48 120). There was no statistical significance between the two groups. However, three patients in DPP4is group showed transient elevation of serum amylase levels (157, 183, 209 respectively). Thus, the incidence of elevated serum pancreatic amylase levels beyond normal range was calculated as $6.12 \%$ in DPP4is group although the frequency was 0\% in GLP1 analog group. The increased serum amylase levels in those three patients were returned within normal range after the termination of DPP4is in less than 4 months. None of them showed any clinical symptom and abnormality in abdominal echo gram examinations.

One strength of the current study is that the serum amylase levels were consistently measured in all patients with T2DM in the current population every other month through the entire observation period. Measurement of serum amylase level consistently might have meaning to catch the onset of pancreatitis and minimize the side effects of DPP4is and GLP-1 analogs.

\section{Abbreviations}

DPP4i: Dipeptidyl peptidase-4 inhibitor

\section{Acknowledgements}

Not applicable.

\section{Authors' contributions}

All authors had active participation in the preparation of the manuscript. All authors read and approved the final manuscript.

\section{Funding}

This research did not receive any specific grant from funding agency in the public or commercial sector or from any of the co-authors.

\section{Availability of data and materials}

Not applicable.

\section{Ethics approval and consent to participate}

This study was approved by the Ethics Committee of Gunma University Hospital. A written informed consent was obtained from the subject to publish this manuscript and any accompanying images. A copy of this consent is available for review by the Editor-in-Chief of this journal. All procedures followed in this study complied with the ethical standards of the responsible committee for human experimentation (institutional and national) and with the Helsinki Declaration of 1975, as revised in 2008.

\section{Consent for publication}

All participants understand that the information will be published anonymously, but that full anonymity cannot be guaranteed. We understand that the text and any pictures or videos published in the article will be freely available on the Internet and may be seen by the general public. Pictures, videos, and text may also appear on other websites or in print and may be translated into other languages or used for commercial purposes.

\section{Author details}

'Department of Medicine and Molecular Science, Gunma University Graduate School of Medicine, 3-39-15 Showa-machi, Maebashi, Gunma 371-8511, Japan. ${ }^{2}$ Kan-etsu Chuo Hospital, 71 Kitahara, Takasaki, Gunma 370-3513, Japan.

Received: 21 February 2019 Accepted: 28 October 2019

Published online: 14 November 2019

\section{References}

1. Rathish D, Jayasumana C, Agampodi S. Comparison of biochemical parameters among DPP4 inhibitor users and other oral hypoglycaemic drug users: a cross-sectional study from Anuradhapura, Sri Lanka. J Health Popul Nutr. 2019;38(1):3. https://doi.org/10.1186/s41043-019-0160-X.

2. Thomsen RW, Pedersen L, Møller N, Kahlert J, Beck-Nielsen H, Sørensen HT. Incretin-based therapy and risk of acute pancreatitis: a nationwide population-based-control study. Diabetes Care. 2015;38:1089-98.

3. Sesti G, Avogaro A, Belcastro S, Bonora BM, Croci M, Daniele G, Dauriz M, Dotta F, Formichi C, Frontoni S, Invitti C, Orsi E, Picconi F, Resi V, Bonora E, Purrello F. Ten years of experience with DPP-4 inhibitors for the treatment of type 2 diabetes mellitus. Acta Diabetol. 2019. https://doi.org/10.1007/ s00592-018-1271-3.

4. Niijima K, Muranaka Y, Ando T, Okada S, Niijima Y, Hashimoto K, Yamada M, Ohshima K, Mori M, Ono K. Elevated 1-h plasma glucose following 75-g oral glucose load is a predictor of arterial stiffness in subjects with normal glucose tolerance. Diabet Med. 2012;29(12):e457-e460.

\section{Publisher's Note}

Springer Nature remains neutral with regard to jurisdictional claims in published maps and institutional affiliations.
Ready to submit your research? Choose BMC and benefit from:
- fast, convenient online submission
- thorough peer review by experienced researchers in your field
- rapid publication on acceptance
- support for research data, including large and complex data types
- gold Open Access which fosters wider collaboration and increased citations
- maximum visibility for your research: over $100 \mathrm{M}$ website views per year
At $\mathrm{BMC}$, research is always in progress.
Learn more biomedcentral.com/submission 